\title{
Pembuatan Graphic User Interface (GUI) untuk Analisis Ayunan Matematis Menggunakan Matlab
}

\author{
Nurullaeli ${ }^{1 *}$ dan Irnin Agustina Dwi Astuti² \\ ${ }_{1}$ Program Studi Informatika, Universitas Indraprasta PGRI \\ ${ }^{2}$ Program Studi Pendidikan Fisika, Universitas Indraprasta PGRI \\ *E-mail: leli.biofisika@gmail.com
}

\begin{abstract}
Abstrak
Penelitian ini bertujuan untuk membuat Graphic User Interface (GU ) yang digunakan sebagai alat analisis konsep ayunan matematis. Pokok bahasan yang dibahas mengenai ayunan matematis karena materi tersebut berkaitan dengan persamaan deferensial yang membutuhkan ketelitian tinggi dan keahlian dalam perhitungannya. Metode yang digunakan dalam analisis yaitu metode regresi linier, Rungge-Kutta orde 4 (RK4), dan ode45. Metode tersebut ditulis dalam sintak bahasa pemrograman Matlab dan disajikan dalam bentuk GUI. Metode regresi linier digunakan untuk menghitung percepatan gravitasi bumi, sedangkan metode RK4 dan ode45 digunakan untuk analisis lebih dalam mengenai konsep ayunan matematis. Pada penelitian ini didapatkan hasil perhitungan untuk percepatan gravitasi bumi $(9.5549 \pm 0.29363) \mathrm{m} / \mathrm{s}^{2}$. Metode ode45 pada penelitian ini menunjukkan hasil yang lebih teliti dalam analisis konsep ayunan matematis pada rentang waktu yang panjang. Hasil penelitian ini dapat digunakan sebagai media pembelajaran dan alat bantu analisis pada pokok bahasan ayunan matematis untuk meminimalisir kesalahan perhitungan dan menghemat waktu.
\end{abstract}

Kata kunci: graphic user interface, Matlab, metode regresi linear, metode Rungge-Kutta, metode ode45.

\section{PENDAHULUAN}

Fisika dasar pada umumnya dipelajari dengan alat-alat praktikum fisika sederhana yang pengukurannya masih manual. Pada kegiatan praktikum fisika dasar kemudahan dan kepraktisan dalam proses pelaksanaannya merupakan satu tuntutan yang harus diperhatikan karena selain dapat meningkatkan kinerja paraktikum sekaligus juga dapat mengoptimalkan waktu kegiatan praktikum mahasiswa. Setiap gerak yang terjadi secara berulang dalam selang waktu yang sama disebut gerak periodik. Gerak periodik yang terjadi secara teratur disebut gerak harmonis. Osilator harmonik atau gerak harmonik sederhana merupakan fenomena fisis yang sering dijumpai dalam kehidupan sehari hari dan sering dilakukan untuk kegiatan praktikum mahasiswa karena konsepnya yang dasar. Gerak harmonik merupakan gerak bolak - balik benda melalui suatu titik keseimbangan tertentu dengan banyaknya getaran benda dalam setiap detik selalu konstan (Syahrul, 2013).

Fenomena osilator harmonik salah satunya digunakan untuk menentukan percepatan gravitasi bumi. Penentuan besar percepatan gravitasi bumi menggunakan ayunan matematis dengan berbagai metode analisis pengukuran juga pernah dilakukan oleh Chusni (2017) secara manual. Pengambilan data dilakukan dengan cara melepaskan bandul yang diikatkan pada tali yang tergantung kemudian dicatat waktunya. Pengolahan data dilakukan dengan metode pengukuran tunggal, pengukuran berulang, pengukuran ulang dengan rata-rata berbobot, dan regresi linear tanpa bobot. Dari data eksperimen diperoleh besar percepatan gravitasi bumi menggunakan metode pengukuran tunggal sebesar $(9.689 \pm 0.009) \mathrm{m} / \mathrm{s}^{2}$, pengukuran berulang sebesar $(9,832 \pm 0,001) \mathrm{m} / \mathrm{s}^{2}$, pengukuran berulang dengan rata-rata berbobot sebesar $(9,835 \pm 0,004) \mathrm{m} / \mathrm{s}^{2}$, dan pengukuran dengan regresi linier tanpa bobot sebesar $(9,71 \pm 0,43) \mathrm{m} / \mathrm{s}^{2}$. Pada pengukuran ini membutuhkan waktu yang lama untuk analisis data karena mengambil data secara berkali-kali kemudian dianalisis secara manual. Selain dengan metode di atas percepatan gravitasi bumi juga dapat dilakukan dengan metode lain. Berdasarkan hasil analisis tracker yang dilakukan oleh Afifah (2015) melalui percobaan gerak parabola diperoleh nilai percepatan gravitasi Bumi di daerah Bandung yaitu rata-rata sebesar $-9,676$ 
$\mathrm{m} / \mathrm{s}^{2}$, tanda negatif menunjukkan arah percepatan ke bawah. Hasil ini memiliki nilai yang kurang mendekati dengan ralat relatif $1,26 \%$. Penelitian lainnya yang sejalan oleh Astuti (2016), menjelaskan bahwa penentuan percepatan gravitasi bumi bisa dilakukan dengan berbantuan sensor yaitu dengan Microcomputer Based Laboratory (MBL) dan dianalisis dengan software Logger Pro sehingga didapatkan nilai percepatan gravitasi bumi sebesar $9,895 \mathrm{~m} / \mathrm{s}^{2}$. Tetapi dalam penelitiannya masih kurang efektif karena membutuhkan waktu yang lama untuk membuat alat peraga dan mengujinya.

Fenomena fisis osilator harmonik dinyatakan dalam model matematis yaitu persamaan diferensial. Solusi persamaan osilator harmonik dapat diselesaikan melalui pendekatan analitik. Analisis osilator harmonik ini sering dilakukan dalam praktikum untuk menganalisis gejala-gejalanya seperti ayunan matematis untuk menentukan nilai percepatan gravitasi bumi. Analisis osilator harmonik membutuhkan waktu yang lama jika dianalisis secara manual karena membutuhkan kemampuan perhitungan diferensial yang baik dan membutuhkan ketelitian yang tinggi. Mahasiswa masih menganalisis satu persatu data yang sudah diperoleh dari hasil praktikum. Biasanya hasil analisis juga kurang akurat dan masih terjadi kesalahan hitung dan mempunyai eror yang tinggi. Ini mengakibatkan analisis secara manual belum efektif.

Newton pernah menyimpulkan bahwa ada gaya gravitasi yang mempengaruhi benda di bumi, konsep Newton tersebut sangatlah berpengaruh di dunia fisika sampai sekarang ini. Dengan konsepnya tersebut, Newton berhasil menentukan besar percepatan gravitasi yang ada di perumukaan dataran rendah yaitu $9,8 \mathrm{~ms}^{2}$. Percepatan gravitasi dipengaruhi oleh posisi ketinggian dan massa benda maka besar percepatan gravitasi tiap daerah itu akan berbeda.

Persamaan osilator harmonik dinyatakan dalam persamaan diferensial biasa. Karakteristik persamaan diferensial biasa umumnya dapat diselesaikan menggunakan metode analitik. Namun, pada bentuk kompleks persamaan diferensial biasa tidak dapat dengan mudah ditentukan penyelesaian analitiknya. Oleh karena itu, dikembangkan berbagai metode numerik untuk menyelesaikan persamaan diferensial biasa. Metode numerik disebut juga sebagai metode alternatif dari metode analitik, yang merupakan metode penyelesaian persoalan matematika dengan rumusrumus aljabar yang sudah baku atau lazim (Costa, 2014). Di dalam metode numerik ini dilakukan operasi hitungan yang berulang-ulang untuk menyelesaikan penyelesaian numeriknya. Penyelesaian numerik ditentukan dengan melakukan prosedur perulangan (iterasi) tertentu, sehingga setiap hasil akan lebih teliti dari perkiraan sebelumnya. Dengan melakukan prosedur perulangan yang dianggap cukup akhirnya diperoleh hasil perkiraan yang mendekati nilai eksak. Nilai eksak tersebut hanya dapat diketahui apabila suatu fungsi $f(x)$ bisa diselesaikan secara analitis (Gatot, 2011).

Matlab merupakan bahasa pemrograman komputer berbasis windows dengan orientasi dasarnya adalah matrik, namun pada program ini tidak menutup kemungkinan untuk pengerjaan permasalahan non matrik (Rahman, 2014). Pada pemrograman Matlab bisa menggunakan metode Runge-Kutta orde 4 dan ode45. Metode Runge-Kutta orde 4 adalah suatu metode yang digunakan untuk menyelesaikan persamaan diferensial secara numerik atau pendekatan sehingga mendapatkan penyelesaian yang lebih signifikan atau handal dari pada penyelesaian secara eksak atau analitik (Costa, 2014). Metode lain yang populer untuk menyelesaikan persamaan diferensial biasa adalah RKF45. Metode ini dalam bahasa pemrograman Matlab disediakan dalam fungsi panggilan ode45. Menurut Chapra (2012) fungsi ode45 menggunakan algoritma yang dikembangkan oleh Dormand and Prince (1980), yang sekaligus menggunakan formula RK4 dan RK5 untuk mencari solusi. Matlab merekomendasikan ode45 sebagai fungsi yang diterapkan terlebih dahulu untuk sebagian besar masalah. Kemampuan setiap mahasiswa dalam menggunakan Matlab tidak sama, ada beberapa mahasiswa yang kurang mahir dalam menulis sintak program sehingga bahasa pemrograman yang diharapkan mempermudah dalam menyelesaikan persamaan deferensial pada ayunan matematis malah menjadi rumit. Oleh sebab itu, diperlukan suatu graphic user interface (GUI) yang dapat langsung digunakan oleh mahasiswa untuk perhitungan atau analisis persamaan matematik tersebut. GUI Matlab digunakan sebagai alat komputasi untuk melakukan pengambilan keputusannya (Netra, 
2016).

Dalam penelitian ini, peneliti membuat graphic user interface (GUI) untuk analisis konsep ayunan matematis. Metode yang dipakai pada penelitian ini adalah regresi linear, Runge-Kutta orde 4, dan ode45. Penelitian ini diharapkan dapat memberikan kontribusi dalam dunia pendidikan berupa graphic user interface (GUI) untuk analisis ayunan matematis yang efektif dan efisien. GUI ini dapat digunakan sebagai media pembelajaran dan alat bantu analisis pada pokok bahasan ayunan matematis. Penggunaan GUI ini akan meminimalisir kesalahan perhitungan dan menghemat waktu dalam analisis ayunan matematis.

\section{METODE}

Penelitian ini dilaksanakan di Laboratorium Fisika Universitas Indraprasta PGRI. Peralatan yang digunakan dalam penelitian yaitu, sebuah laptop dengan prosesor Intel Core i5-2450M, 2.5 $G H z, H D D 640 G B$, memori 4 GB. Software yang digunakan dalam penelitian ini adalah bahasa pemrograman Matlab (Matrix Laboratory) R2013a dan MS. Office 2010. Data penelitian yang diperoleh dari hasil percobaan ayunan matematis kemudian dianalisis dan dibandingkan hasilnya dengan analisis numerik dengan bantuan Matlab. Analisis numerik pada ayunan matematis menggunakan metode regresi linier, RK4, dan ode45 dengan bantuan software Matlab.

Ayunan matematis adalah suatu benda digantungkan pada suatu titik tetap dengan tali. Jika ayunan menyimpang sebesar sudut $\theta$ terhadap garis vertikal maka gaya yang mengembalikan, yaitu

$$
F=-m g \sin \theta
$$

Untuk $\theta$ kecil maka $\sin \theta=\theta=\mathrm{s} / \mathrm{l}$, dimana $\mathrm{s}=$ busur lintasan bola dan I = panjang tali , sehingga

$$
F=-\frac{m g s}{l}
$$

Kalau tidak ada gaya gesekan dan gaya puntiran maka persamaan gaya menjadi

$$
m a=-\frac{m g s}{l}
$$

Pada persamaan osilator harmonik berlaku

$$
a=-\omega^{2} s=-\left(\frac{2 \pi}{T}\right)^{2} s
$$

Apabila persamaan (4) disubsitusikan ke persamaan (3) akan didapatkan

$$
\begin{aligned}
& \frac{4 \pi^{2}}{T^{2}}=\frac{g}{l} \\
& g=\frac{4 \pi^{2} l}{T^{2}} \\
& T^{2}=\frac{4 \pi^{2}}{g} l
\end{aligned}
$$

dengan: $T^{2}=$ kuadrat periode osilasi dan $I=$ panjang tali $(\mathrm{m})$.

Percepatan gravitasi bumi dapat dicari menggunakan metode regresi linear. Persamaan regresi linier untuk ayunan matematis didapatkan dengan perhitungan sebagai berikut

$$
\bar{y}=a \bar{x}+b
$$

dengan persamaan

$$
a=\frac{n \sum\left(x_{i} y_{i}\right)-\sum x_{i} \sum y_{i}}{n \sum x_{i}^{2}-\left(\sum x_{i}\right)^{2}}
$$




$$
b=\frac{\sum y_{i}}{n}-a \frac{\sum x_{i}}{n}=\bar{y}-a \bar{x}
$$

Hasil dari persamaan di atas dapat digunakan untuk menentukan pasangan titik-titik $\left(x_{i}, y_{i}\right)$ yang akan memberi garis lurus pendekatan terbaik.

Sesuai dengan fitting grafik hubungan antara kuadrat periodik (sebagai sumbu y) terhadap panjang tali (sebagai sumbu $\mathrm{x}$ ), maka diperoleh persamaan gradien

$$
a=\frac{T^{2}}{l}
$$

Apabila persamaan (11) disubsitusikan ke persamaan (7) akan didapatkan

$$
a=\frac{4 \pi^{2}}{g}
$$

Sehingga untuk menentukan percepatan gravitasi bumi dapat dihitung menggunakan persamaan

$$
g=\frac{4 \pi^{2}}{a}
$$

Dengan ketidakpastian $S_{a}$ dan $S_{g}$ seperti persamaan di bawah ini

$$
\begin{aligned}
& S_{a}=\sqrt{\frac{\sum\left(y_{i}-\hat{y}_{i}\right)^{2}}{n-2}} \sqrt{\frac{n}{n \sum x^{2}-\left(\sum x\right)^{2}}} \\
& S_{g}=\frac{4 \pi^{2}}{a^{2}} S_{a}
\end{aligned}
$$

Kuantifikasi kesalahan dari regresi linier dapat dianalisis menggunakan persamaan sebagai berikut

$$
\begin{aligned}
& S_{t}=\sum\left(y_{i}-\bar{y}\right)^{2} \\
& S_{r}=\sum_{i=1}^{n} e_{i}^{2}=\sum_{i=1}^{n}\left(y_{i}-b-a x_{i}\right)^{2} \\
& r^{2}=\frac{S_{t}-S_{r}}{S_{t}} \\
& r^{2}=\frac{n \sum\left(x y_{i}\right)-\left(\sum x_{i}\right)\left(\sum y_{i}\right)}{\sqrt{n \sum x_{i}^{2}-\left(\sum x_{i}\right)^{2}} \sqrt{n \sum y_{i}^{2}-\left(\sum y_{i}\right)^{2}}}
\end{aligned}
$$

Nilai dari $r^{2}$ digunakan untuk mengetahui pengaruh variabel bebas terhadap variabel terikat, $r^{2}$ disebut sebagai koefisien deterministik.

Perhitungan percepatan gravitasi dan koefisien deterministik dilakukan dengan bantuan software Matlab, dimana persamaan-persamaan matematis di atas terlebih dahulu ditulis dalam sintak bahasa pemrograman Matlab dan diuji coba untuk perhitungan data penentuan percepatan gravitasi yang telah didapatkan pada eksperimen di laboratorium.

Metode Runge-Kutta merupakan metode dengan pendekatan deret Taylor. Pada penelitian ini digunakan metode Runge-Kutta orde 4 (RK4) yang dapat dituliskan sebagai berikut

$$
\begin{aligned}
& k_{1}=f\left(x_{n}, y_{n}\right) \\
& k_{2}=f\left(x_{n}+\frac{h}{2}, y_{n}+\frac{h k_{1}}{2}\right) \\
& k_{3}=f\left(x_{n}+\frac{h}{2}, y_{n}+\frac{h k_{2}}{2}\right)
\end{aligned}
$$




$$
\begin{aligned}
& k_{4}=f\left(x_{n}+h, y_{n}+h k_{3}\right) \\
& y_{n+1}=y_{n}+h\left(\frac{k_{1}}{6}+\frac{k_{2}}{3}+\frac{k_{3}}{3}+\frac{k_{4}}{6}\right)
\end{aligned}
$$

Persamaan pada ayunan matematis dianalisis menggunakan RK4. Persamaan diferensial orde ke 2 pada ayunan matematis akan diganti dengan 2 persamaan linier. Persamaan tersebut akan ditulis dalam sintak bahasa Matlab untuk mempermudah analisis.

Analisis numerik ayunan matematis juga dilakukan menggunakan ode45. Pemanggilan fungsi ode45 pada Matlab sebagai berikut :

$[t, y]=$ ode 45 ('fname', tspan, y0);

keterangan :

fname : nama fungsi dari Mfile yang digunakan.

tspan : dua elemen vektor yang mendefinisikan rentang dari waktu awal dan waktu akhir.

y0 : vektor dari kondisi awal untuk variabel $\mathrm{y}$.

Setelah didapatkan hasil analisis numerik, dibuat GUI untuk perhitungan percepatan gravitasi, perhitungan konstanta pegas, dan analisis ayunan matematis dengan metode RK4 serta ode 45.

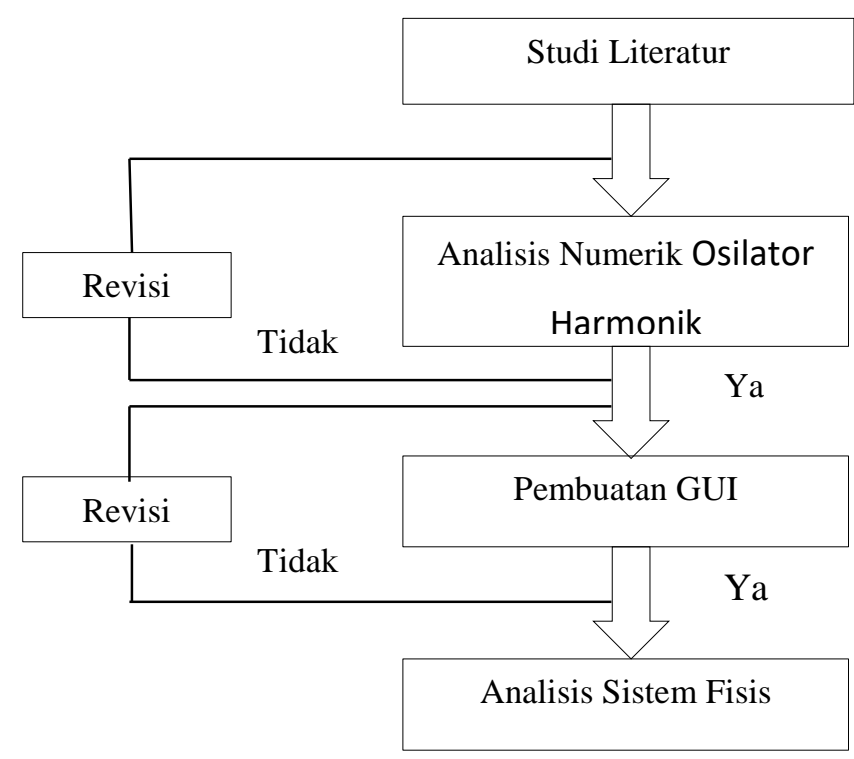

Gambar 1. Diagram Alir Penelitian

\section{HASIL DAN PEMBAHASAN}

Analisis numerik pada ayunan matematis menggunakan metode regresi linier, RK4, dan ode45 dengan bantuan software Matlab. Analisis numerik ini dilakukan untuk memudahkan perhitungan pada persamaan diferensial biasa pada ayunan matematis yang jika diselesaikan menggunakan metode analitik membutuhkan waktu yang lama. 
Tabel 1. Data Eksperimen Ayunan Matematis

\begin{tabular}{cccc}
\hline No & $\boldsymbol{L}(\mathbf{x})$ & $\boldsymbol{T}$ & $\boldsymbol{T}^{2}(\mathbf{y})$ \\
\hline 1 & 0.3 & 1.224 & 1.498176 \\
2 & 0.35 & 1.265 & 1.600225 \\
3 & 0.4 & 1.316 & 1.731856 \\
4 & 0.45 & 1.395 & 1.946025 \\
5 & 0.5 & 1.442 & 2.079364 \\
6 & 0.55 & 1.526 & 2.328676 \\
7 & 0.6 & 1.579 & 2.493241 \\
8 & 0.65 & 1.648 & 2.715904 \\
9 & 0.7 & 1.705 & 2.907025 \\
10 & 0.75 & 1.789 & 3.200521 \\
11 & 0.8 & 1.808 & 3.268864 \\
12 & 0.85 & 1.876 & 3.519376 \\
13 & 0.9 & 1.935 & 3.744225 \\
14 & 0.95 & 2.026 & 4.104676 \\
15 & 1 & 2.112 & 4.460544 \\
\hline
\end{tabular}

Persamaan-persamaan regresi linier pada persamaan (2) dan (3) tersebut diubah ke dalam bahasa Matlab untuk mempermudah dan mempercepat perhitungan. Pada penelitian ini didapatkan hasil perhitungan untuk percepatan gravitasi sebesar $(9.5549 \pm 0.29363) \mathrm{m} / \mathrm{s}^{2}$. Data eksperimen ayunan matematis yang dipakai tercantum pada tabel 1 .

RK4 yang digunakan untuk analisis ayunan matematis menggunakan pendekatan deret Taylor. Ayunan matematis yang terdiri dari batang dengan panjang / dengan titik massa sebesar $m$ terpasang di bagian bawah batang. Persamaan pada ayunan matematis dapat ditulis sebagai berikut

$$
\frac{d^{2} \phi}{d t^{2}}+\frac{g}{l} \sin \phi=0
$$

dengan $\phi$ adalah sudut simpangan dan $g$ adalah percepatan gravitasi. Pada penelitian ini, persamaan diselesaikan menggunakan metode RK4. Persamaan pada ayunan matematis tersebut diubah menjadi dua persamaan diferensial biasa sebagai berikut

$$
\begin{aligned}
& \frac{d \phi}{d t}=z \\
& \frac{d z}{d t}=-\frac{g}{l} \sin (\phi)
\end{aligned}
$$

Dari kedua persamaan tersebut akan didapatkan hasil analisis ayunan matematis. Simulasi untuk analisis ayunan matematis dapat dilihat pada GUI. Metode lain yang dipakai dalam penelitian ini untuk menyelesaikan persamaan diferensial biasa adalah RKF45. Metode ini dalam bahasa pemrograman Matlab disediakan dalam fungsi panggilan ode45 yang menggunakan formula RK4 dan RK5 untuk mencari solusi.

GUI terbagi menjadi beberapa bagian tampilan, yaitu bagian tampilan awal, bagian regresi linear untuk perhitungan percepatan gravitasi bumi, bagian analisis ayunan matematis menggunakan metode RK4 dan ode45. Pada tampilan awal dapat dipilih menu home, regresi linear untuk analisis ayunan matematis (penentuan percepatan gravitasi bumi) menggunakan metode RK4 dan ode45. Tampilan awal GUI dapat dilihat pada gambar 2. 


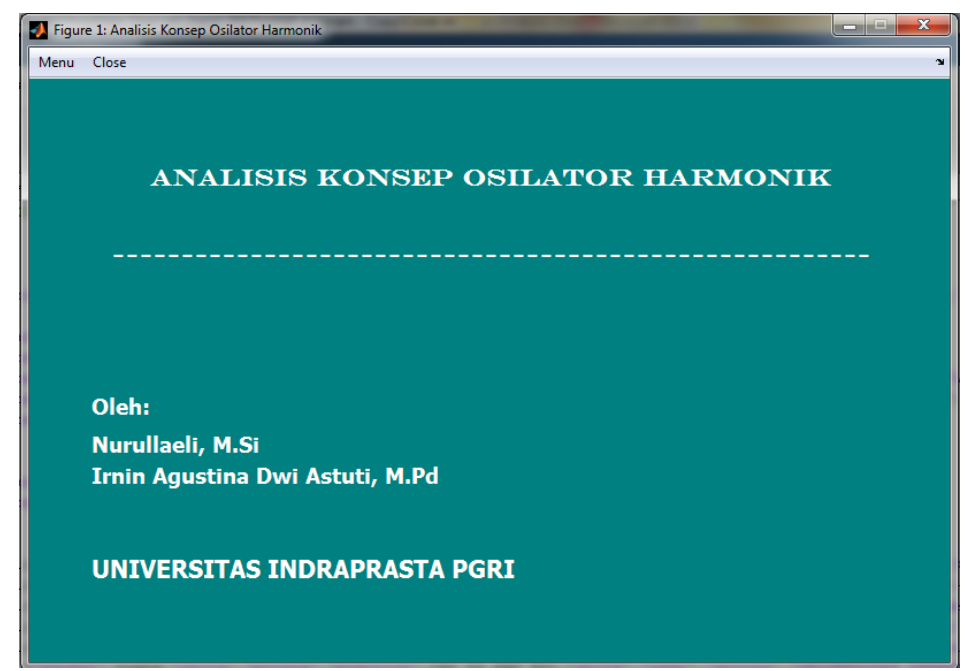

Gambar 2. Tampilan Awal GUI

Menu regresi linear untuk ayunan matematis digunakan dalam perhitungan percepatan gravitasi bumi. GUI regresi linear ini diharapkan dapat mempermudah dan mempercepat perhitungan percepatan gravitasi bumi yang biasanya membutuhkan waktu lama dan ketelitian yang tinggi saat analisis data percobaan. Hasil perhitungan percepatan gravitasi bumi dapat dilihat pada gambar 3 .

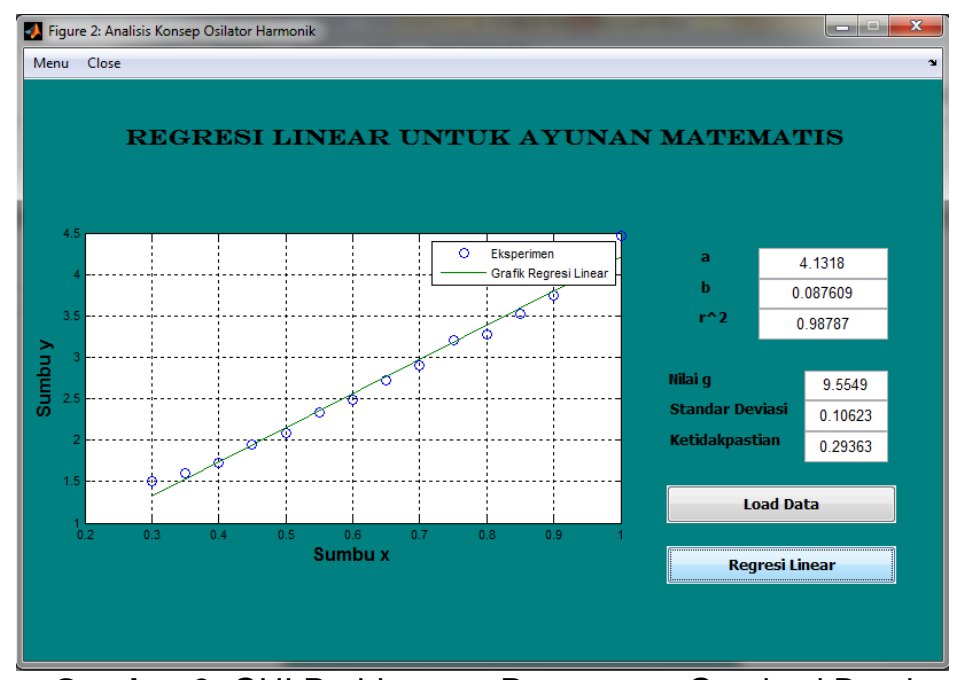

Gambar 3. GUI Perhitungan Percepatan Gravitasi Bumi

Data yang didapat ditulis pada Notepad terlebih dahulu dan disimpan dengan nama dataku, data tersebut dipanggil di GUI dengan cara menekan tombol Load Data. Setelah muncul data yang dipanggil maka dilakukan analisis dengan menekan tombol Regresi Linear. Grafik hasil regresi linear akan terbentuk dan nilai dari variabel $a, b$, koefisien deterministik, percepatan gravitasi bumi, standar deviasi, dan ketidakpastian akan diperoleh. Dalam penelitian ini didapatkan nilai $a=4.1318, \quad b=$ $0.087609, r^{2}=98.787 \%$, percepatan gravitasi $9.5549 \mathrm{~m} / \mathrm{s}^{2}$, standar deviasi 0.10623 , dan ketidakpastian 0.29363 .

Menu analisis ayunan matematis menggunakan metode RK4 dan ode45 digunakan untuk mengetahui pengaruh nilai masukan pada bentuk grafik ayunan matematis. Nilai masukan tersebut terdiri dari percepatan gravitasi bumi, panjang tali, sudut mula-mula, selang waktu, dan jumlah langkah pengulangan. Pada GUI yang dibuat terdapat dua pilihan analisis, yaitu dapat menggunakan metode RK4 dan ode45. Hasil yang diperoleh dari kedua metode hampir sama, tetapi untuk rentang waktu yang lebar ode45 akan memberikan hasil yang lebih mendekati nilai sebenarnya. GUI ini dapat digunakan untuk mempermudah analisis ayunan matematis tanpa harus melakukan percobaan 
terlebih dahulu. Pengguna dapat mengetahui perubahan bentuk grafik jika nilai masukan diganti. Tampilan GUI untuk analisis ayunan matematis dapat dilihat pada gambar 4 dan 5 .

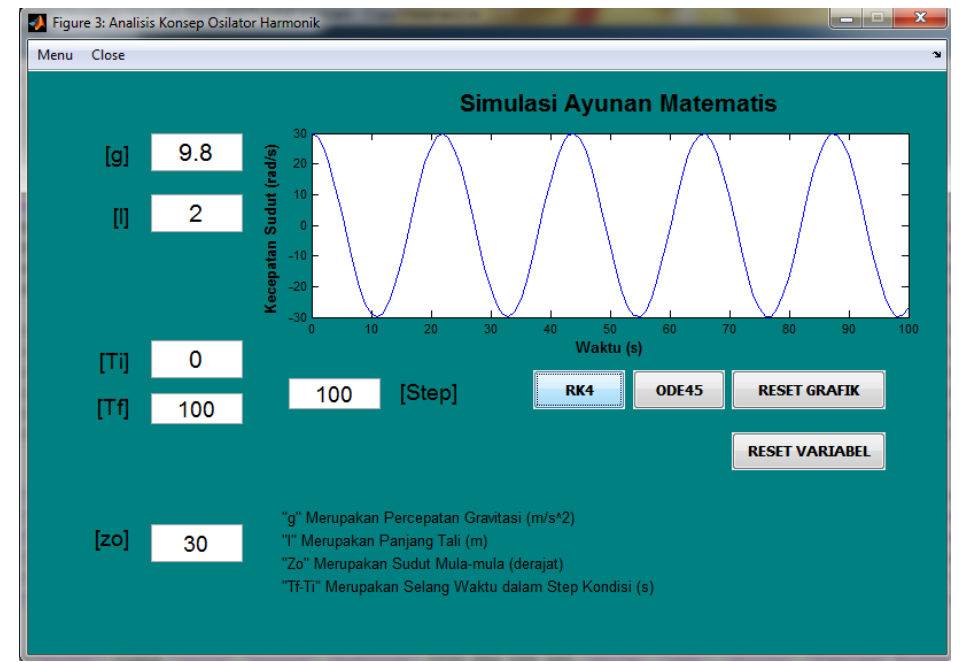

Gambar 4. GUI Analisis Ayunan Matematis Menggunakan Metode RK4

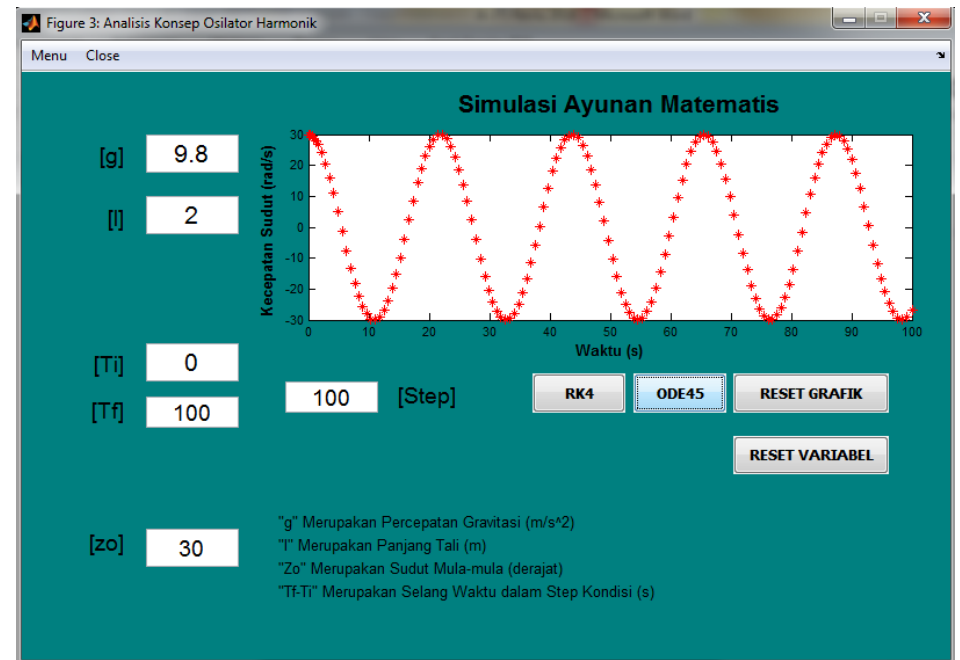

Gambar 5. GUI Analisis Ayunan Matematis Menggunakan Metode ode45

Newton pernah menyimpulkan bahwa ada gaya gravitasi yang mempengaruhi benda di bumi, konsep Newton tersebut sangatlah berpengaruh di dunia fisika sampai sekarang ini. Dengan konsepnya tersebut, Newton berhasil menentukan besar percepatan gravitasi yang ada di bumi yaitu 9,8 $\mathrm{ms}^{-2}$. Percepatan gravitasi dipengaruhi oleh posisi ketinggian dan massa benda maka besar percepatan gravitasi tiap daerah itu akan berbeda. Berbagai upaya untuk melakukan eksperimen penentuan percepatan gravitasi bumi. Ada yang dilakukan dengan cara konvensional atau manual, ada yang menggunakan cara digital dengan berbantuan komputer, dan yang lain sebagainya.

Dengan adanya GUI ini dapat mempermudah dalam analisis konsep osilator harmonik. Tampilan GUI yang menarik ini bisa membuat pengguna, khususnya mahasiswa menjadi lebih nyaman dan tidak terkesan monoton. GUI dapat digunakan sebagai media pembelajaran dan alat bantu analisis pada pokok bahasan osilator harmonik ayunan matematis tanpa harus melakukan perhitungan panjang secara manual. Penggunaan GUI ini akan meminimalisir kesalahan perhitungan dan menghemat waktu dalam menghitung percepatan gravitasi bumi dan menganalisis konsep osilator harmonik dalam ayunan matematis. Dalam analisis konsep osilator harmonik, metode numerik ode45 mempunyai keunggulan dibanding RK4. Analisis menggunakan metode ode45 lebih mendekati nilai sebenarnya.

Kegiatan eksperimen berbasis komputer memerlukan satu perangkat pengumpul data dan 
program pendukungnya yang sesuai dengan besaran yang akan diukur. Penggunaan perangkat sederhana ini menghasilkan data yang lebih akurat atau mendekati dengan nilai referensi. Tidak membutuhkan waktu lama untuk menganalisisnya dibandingkan dengan eksperimen metode konvensional. Dengan menggunakan Matlab ini merupakan salah satu alternatif atau inovasi baru dalam eksperimen fisika sehingga memudahkan siswa/mahasiswa dalam melaksanakan praktikum dengan waktu yang efektif.

\section{PENUTUP}

Graphic User Interface (GUI) dapat digunakan sebagai media pembelajaran dan alat bantu analisis ayunan matematis. Penggunaan GUI ini akan meminimalisir kesalahan perhitungan dan menghemat waktu dalam analisis ayunan matematis. GUI ini juga dapat digunakan untuk menghitung percepatan gravitasi bumi dan diperoleh nilai percepatan gravitasi bumi sebesar (9.5549 \pm 0.29363 ) $\mathrm{m} / \mathrm{s}^{2}$. Dalam analisis konsep ayunan matematis, metode numerik ode45 mempunyai keunggulan dibanding RK4. Analisis menggunakan metode ode45 lebih mendekati nilai sebenarnya.

\section{UCAPAN TERIMAKASIH}

Apresiasi dan terima kasih kepada Lembaga Penelitian dan Pengabdian Masyarakat Universitas Indraprasta PGRI yang telah membiayai penelitian ini, serta pengelola Jurnal Ilmiah Multi Sciences yang telah bersedia mempublikasikan hasil penelitian ini.

\section{REFERENSI}

Afifah, D. N., Yulianawati, D., Agustina, N., Lestari, R. D. S., \& Nugraha, M. G. (2015). Metode Sederhana Menentukan Percepatan Gravitasi Bumi Menggunakan Aplikasi Tracker Pada Gerak Parabola Sebagai Media dalam Pembelajaran Fisika SMA. Simposium Nasional Inovasi dan Pembelajaran Sains (SNIP), Bandung, 305-308.

Astuti, I. A. D. (2016). Pengembangan Alat Eksperimen Penentuan Percepatan Gravitasi Bumi Berdasarkan Teori Bidang Miring Berbasis Microcomputer Based Laboratory (MBL). Faktor Exacta, 9(2), 114-118.

Chapra SC. (2012). Applied numerical methods with MATLAB® for engineers and scientists third edition. New York: McGraw-Hill.

Chusni, M. M. (2017). Penentuan Besar Percepatan Gravitasi Bumi Menggunakan Ayunan Matematis dengan Berbagai Metode Pengukuran. Scientiae Educatia: Jurnal Pendidikan Sains, 6(1), 47-53.

Costa, José Da, Suryasatriya Trihandaru, \& Made Rai Suci Santi. (2014). Analisis Numerik untuk Gerak Osilasi Bergandeng pada Air Track dengan Metode Runge-Kutta. Prosiding Pertemuan IImiah XXVIII HFI Jateng \& DIY, Yogyakarta, 26 April 2014.

Gatot, F., \& Santoso, I. (2012). Analisis Perbandingan Metode Numerik Dalam Menyelesaikan PersamaanPersamaan Serentak. Widya Warta, 35(01), 19-39.

Netra, P. A., Widiharih, T., \& Yasin, H. (2016). Gui Matlab Untuk Kombinasi Metode Analytic Hierarchy Process (Ahp) Dan Topsis Dalam Pemilihan Cafe Terfavorit (Studi Kasus: Pemilihan Cafe Terfavorit Di Daerah Tembalang, Semarang). Jurnal Gaussian, 5(3), 515-524.

Rahman,J, M. Mushtaq,A. Ali,Y.N. Anjam \& S.Nazir. (2014). Modeling Damped Mass-Spring System In MATLAB Simulink. Journal of Faculty of Engineering \& Technology, JFET 21(2), 21-28.

Syahrul, Adler J., \& Andriana. (2013). Pengukur Percepatan Gravitasi Menggunakan Gerak Harmonik Sederhana Metode Bandul. Jurnal Teknik Komputer Unikom (Komputika), 2(2) 